\title{
Sedimentary macrofossil records reveal ecological change in English lakes: implications for conservation
}

\author{
Helen Bennion - Carl D. Sayer - Stewart J. Clarke - Thomas A. Davidson • Neil L. Rose • \\ Ben Goldsmith $\cdot$ Ruth Rawcliffe $\cdot$ Amy Burgess $\cdot$ Gina Clarke $\cdot$ Simon Turner • \\ Emma Wiik
}

Received: 30 September 2016/Accepted: 17 January 2017/Published online: 31 January 2017

(C) The Author(s) 2017. This article is published with open access at Springerlink.com

\begin{abstract}
Aquatic macrophytes play a key role in providing habitat, refuge and food for a range of biota in shallow lakes. However, many shallow lakes have experienced declines in macrophyte vegetation in recent decades, principally due to eutrophication. As changes in macrophyte composition and abundance can affect overall ecological structure and function of a lake, an assessment of the timing and nature of such
\end{abstract}

Electronic supplementary material The online version of this article (doi:10.1007/s10933-017-9941-7) contains supplementary material, which is available to authorized users.

H. Bennion $(\bowtie) \cdot$ C. D. Sayer · N. L. Rose

B. Goldsmith · R. Rawcliffe - A. Burgess ·

G. Clarke $\cdot$ S. Turner

Department of Geography, Environmental Change

Research Centre, University College London, Gower

Street, London WC1E 6BT, UK

e-mail: h.bennion@ucl.ac.uk

C. D. Sayer

e-mail: c.sayer@ucl.ac.uk

N. L. Rose

e-mail: n.rose@ucl.ac.uk

B. Goldsmith

e-mail: b.goldsmith@ucl.ac.uk

R. Rawcliffe

e-mail: ruth.rawcliffe@googlemail.com

A. Burgess

e-mail: amy.burgess@ucl.ac.uk

G. Clarke

e-mail: gina.clarke@ucl.ac.uk changes is crucial to our understanding of the wider lake ecosystem. In the typical absence of historical plant records, the macro-remains of macrophytes preserved in lake sediments can be used to assess long-term changes in aquatic vegetation. We generated recent (150-200 years) plant macrofossil records for six English lakes subject to conservation protection to define past macrophyte communities, assess trajectories of ecological change and consider the implications of our findings for conservation targets and strategies. The data for all six lakes reveal a diverse submerged macrophyte community, with charophytes

\section{S. Turner \\ e-mail: simon.turner@ucl.ac.uk}

\section{S. J. Clarke}

The National Trust, c/o Westley Bottom, Bury St Edmunds, Suffolk IP33 3WD, UK

e-mail: stewart.clarke@nationaltrust.org.uk

\section{T. A. Davidson}

Department of Bioscience and Arctic Research Centre (ARC), Aarhus University, Vejlsøvej 25, 8600 Silkeborg, Denmark

e-mail: td@bios.au.dk

E. Wiik

Department of Biology, University of Regina, Regina,

SK, Canada

e-mail: Eme.wiik@gmail.com 
as a key component, in the early part of the sedimentary records. The stratigraphies indicate considerable change to the aquatic vegetation over the last two centuries with a general shift towards species more typically associated with eutrophic conditions. A common feature is the decline in abundance of lowgrowing charophytes and an increase in tall canopyforming angiosperms such as fine-leaved Potamogeton species, Zannichellia palustris and Callitriche species. We hypothesise, based on findings from longterm datasets and palaeoecological records from enriched shallow lakes where plants are now absent, that the observed shifts provide a warning to managers that the lakes are on a pathway to complete macrophyte loss such that nutrient load reduction is urgently needed. It is the sound understanding of present-day plant ecology that affords such reliable interpretation of the fossil data which, in turn, provide valuable context for current conservation decisions.

Keywords Conservation - Eutrophication - Lakes · Macrophytes · Macrofossils · Palaeoecology

\section{Introduction}

Fresh waters have suffered major losses in biodiversity in recent decades being variously impacted by a range of stressors including eutrophication, acidification, airborne pollution, hydromorphological modification, invasive species and climate change (Strayer and Dudgeon 2010; Vörösmarty et al. 2010). One particularly vulnerable group of fresh waters are shallow lakes where decline in species richness, or complete loss, of submerged aquatic macrophytes, largely resulting from eutrophication, has received much attention (Sand-Jensen et al. 2000; Phillips et al. 2016). Since aquatic macrophytes play a central role in providing habitat, refuge and food for a range of biota, and can sequester nutrients and stabilise sediments, changes in their abundance, composition and seasonality can have major consequences for the overall ecological structure and function of a lake (Jeppesen et al. 1998; Sayer et al. 2010a). Hence, aquatic macrophytes are frequently at the heart of lake conservation assessments (Duigan et al. 2007; Penning et al. 2008; Søndergaard et al. 2010).

Changes in a lake's aquatic vegetation can be determined from historical botanical data yet, with a few exceptions (Sand-Jensen 1997; Davidson et al. 2005; Madgwick et al. 2011; Dudley et al. 2012), such records rarely exist for time periods (decades to centuries) sufficient to assess human impacts. An alternative, or indeed complementary, tool for assessing long term changes in vegetation is the palaeoecological record. The macro-remains of aquatic plants such as seeds, fruits, oospores, turions and various vegetative fragments preserve in lake sediments and while it is known that some plant species leave very few, or no remains (e.g. Elodea spp., liverworts) the majority of submerged aquatic plant species are represented in sediments (Birks 1980, 2001, 2007). Notwithstanding the taphonomic issues associated with the plant-macrofossil relationship arising from the varying reproductive strategies and dispersal capabilities of plants, several comparative studies of macrofossil records with botanical records have shown plant macrofossils to reliably record shifts in the dominant aquatic vegetation of shallow lakes (Davidson et al. 2005; Salgado et al. 2010; Clarke et al. 2014; Levi et al. 2014). Plant macrofossils have been variously employed to investigate long-term successional changes in the submerged vegetation of lakes (Bradshaw et al. 2005; Rasmussen and Anderson 2005), responses to recent eutrophication (McGowan et al. 2005; Salgado et al. 2010; Sayer et al. 2010a; Madgwick et al. 2011) and top-down impacts of fish (Sayer et al. 2016), and to inform on lake conservation status and the need for appropriate management (Sayer et al. 2012; Wiik et al. 2014).

The depth, density, diversity and types of aquatic macrophyte present in a lake are important indicators of ecosystem health and are used in lake conservation assessments worldwide such as the National Lakes Assessment in the USA (USEPA 2009) and the lake monitoring programmes for the Water Framework Directive (WFD) in Europe (European Union 2000). In addition to information on contemporary aquatic macrophyte communities, it is increasingly recognised that a knowledge of past vegetation, its influence upon wider lake ecology and the nature and timing of any changes is important for guiding lake management and restoration. The need for a temporal perspective is now enshrined in conservation assessments for European lakes designated as Special Areas of Conservation (SACs) within the EC Habitats and Species Directive (HD) (European Union 1992), whereby if attributes that are characteristic of that lake type are 
present and no significant negative change has been recorded, the lake is judged to be in 'favourable condition'. The UK conservation agencies have developed 'Common Standards for Monitoring' (CSM) guidance to help define 'favourable' condition in detail for lakes (IAFG 2015) and macrophyte community composition and structure are two key elements of the lake assessment.

The requirement to assess the current status of fresh waters relative to some baseline state in the past is encompassed in recent water legislation such as the US Clean Water Act (CWA) (Barbour et al. 2000) and the European Council Water Framework Directive (WFD) (European Union 2000). The WFD requires 'reference conditions' (i.e. those prior to anthropogenic impact) to be determined for a range of biological quality elements (BQEs), and macrophytes are one of the elements that must be defined for lakes (Lyche-Solheim et al. 2013). A lake with BQEs which differ little from the reference condition is classed as having 'High' status, whereas increasing deviation from this reference results in categories of Good, Moderate, Poor and Bad status being attributed. In simple terms, the WFD target is for all waterbodies to be at Good status or better. Consequently, a better understanding of historic plant communities and any ecological changes that may have occurred is important in setting objectives for a particular lake, especially where anthropogenic impacts may have resulted in changes to the character of a site where its 'natural' condition or reference condition is in question. With a few notable exceptions (Ayres et al. 2008; Sayer et al. 2012; Kowalewski et al. 2013; Wiik et al. 2014; Clarke and Lynch 2016), however, there have been few applications of plant macrofossil analysis to directly inform conservation and management. This contrasts with the numerous applied palaeolimnological studies that have defined chemical reference conditions for lakes using transfer functions to assist in management decisions (Dixit et al. 1999; Hall and Smol 2010; Bennion and Simpson 2011). Given that an assessment of ecological change and quality is central to many pieces of environmental legislation, there is a real opportunity for palaeolimnologists to place greater emphasis on the ecological information contained within lake sediment records in order to contribute more fully to conservation decisions.

Here, with examples from six English lakes of conservation interest (Aqualate Mere, Cunswick Tarn,
Hornsea Mere, Over Water, Sunbiggin Tarn and Tatton Mere) (Fig. 1; Table 1), we show how sedimentary macrofossil records can be used to define ecological reference conditions and determine the degree of ecological change in shallow aquatic waterbodies. We focus on plant macrofossil remains but also include zooplankton ephippia to provide complementary information on habitat shifts and potential alterations in the fish community (Davidson et al. 2010). Additionally, we demonstrate how the ecological information contained within sediments can be employed to guide lake conservation decisions. Over the last ten years a number of palaeoecological studies of English lakes, including those featured in this paper, have been commissioned by the UK's regional conservation agency, Natural England. A target of the UK Government is that 50\% of English Sites of Special Scientific Interest (known as SSSIs) will be in favourable condition by 2020 , with at least 95\% of lake sites in favourable or recovering condition (DEFRA 2011). Decision-making on freshwater SSSIs and SACs designated for their freshwater habitat features is founded on the protection and restoration of natural ecosystem function and thus Natural England state that "to know what action is required it is essential to understand the system as it would operate under natural processes and plan from that foundation" (Mainstone et al. 2016). This paper serves to show how palaeoecology can play a valuable role in providing the necessary ecological understanding.

\section{Study sites}

The six study sites are all natural lakes but vary in their geological setting, altitude, water depth, lake area, trophic status and current macrophyte flora (Table 1). One is classed as medium alkalinity, three as high alkalinity and two are classified as "marl", a rare calcareous, high alkalinity lake type which is able to precipitate carbonates and is found in catchments of limestone, chalk or calcareous sandstones. All the lakes are shallow or very shallow according to the WFD lake typology for Great Britain (Phillips 2003). All six lake SSSIs were assessed (as of 2012) as being in 'unfavourable condition' and were classed as Moderate or Poor status in the 2015 WFD classification for both Overall class and ecological status based on biological element 'macrophytes and phytobenthos 
Fig. 1 Location map of study sites

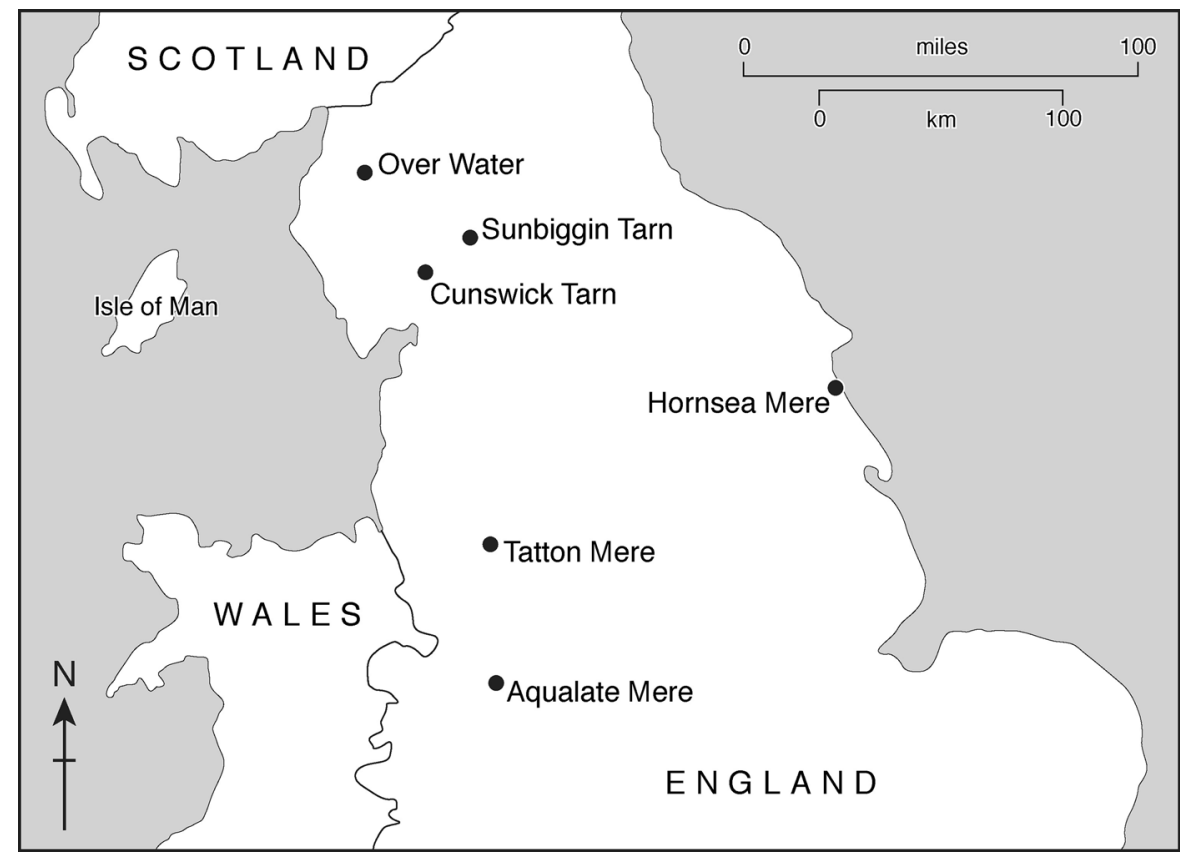

combined' (http://environment.data.gov.uk/catchmentplanning/) (Table 1).

Aqualate Mere, Shropshire, is a high alkalinity lake. It is the largest (75 ha.) of the West Midland meres, a group of waterbodies mostly of glacial/ periglacial origin, recognised as a nationally important nature conservation area. Aqualate Mere occupies a basin in glacial drift overlying Triassic sandstone and is rare amongst the meres in having extensive reedswamp and willow and alder carr. The conservation interest of the open water has declined in recent years due to progressive nutrient enrichment and sedimentation which has reduced the water depth to around $1 \mathrm{~m}$ from an average of $2-3 \mathrm{~m}$ since the $1930 \mathrm{~s}$. Diffuse sources of nutrients and sediments from agriculture in the catchment are thought to have played a part in this process, in addition to potential nutrient inputs from a sewage treatment works which discharged into a canal connected intermittently to the mere. Although phosphorus stripping has now been applied to this discharge, and hence external nutrient loads have been reduced, there is still a large volume of nutrient-rich silt in the mere. At the time of coring, Aqualate Mere was highly eutrophic with total phosphorus (TP), soluble reactive P (SRP), total nitrogen (TN) and chlorophyll $a$ concentrations of $300 \mu \mathrm{g} \mathrm{L}^{-1}$, $200 \mu \mathrm{g} \mathrm{L}^{-1}, 6 \mathrm{mg} \mathrm{L}^{-1}$ and $30-40 \mu \mathrm{g} \mathrm{L}^{-1}$, respectively. At present the mere has an impoverished macrophyte community and has been subject to cyanobacterial blooms which have caused fish kills downstream of the mere. There are plans to undertake dredging to remove this accumulated silt as the first step in restoring the mere to favourable condition. Before these major works took place it was considered prudent to obtain a sediment core to reconstruct the past plant community to inform restoration goals.

Cunswick Tarn, Cumbria, is a marl lake formed in a kettle hole at the foot of a Carboniferous limestone ridge. At the time of designation in 1954, the Tarn was considered to be eutrophic and very little information existed about the composition of the plant community. It has thus been classed as a 'naturally eutrophic lake with Magnopotamion or Hydrocharition-type vegetation' for SSSI assessment purposes (IAFG 2015). The geological setting of the tarn suggests, however, that naturally it might be base-rich and support a plant community typical of a highly calcareous marl lake i.e. abundant charophytes (stoneworts). Nonetheless records from the late 1970s (Stokoe 1983) suggested that the site had not supported a diverse charophyte community for some time, recording only one charophyte species, Chara hispida L., as present. The Tarn is currently eutrophic with mean annual TP of $56 \mu \mathrm{g} \mathrm{L}^{-1}$ and algal blooms occur in summer months. Macrophytes grow to approximately $4 \mathrm{~m}$ depth and are dominated by two species, Nuphar lutea (L.) Sm 


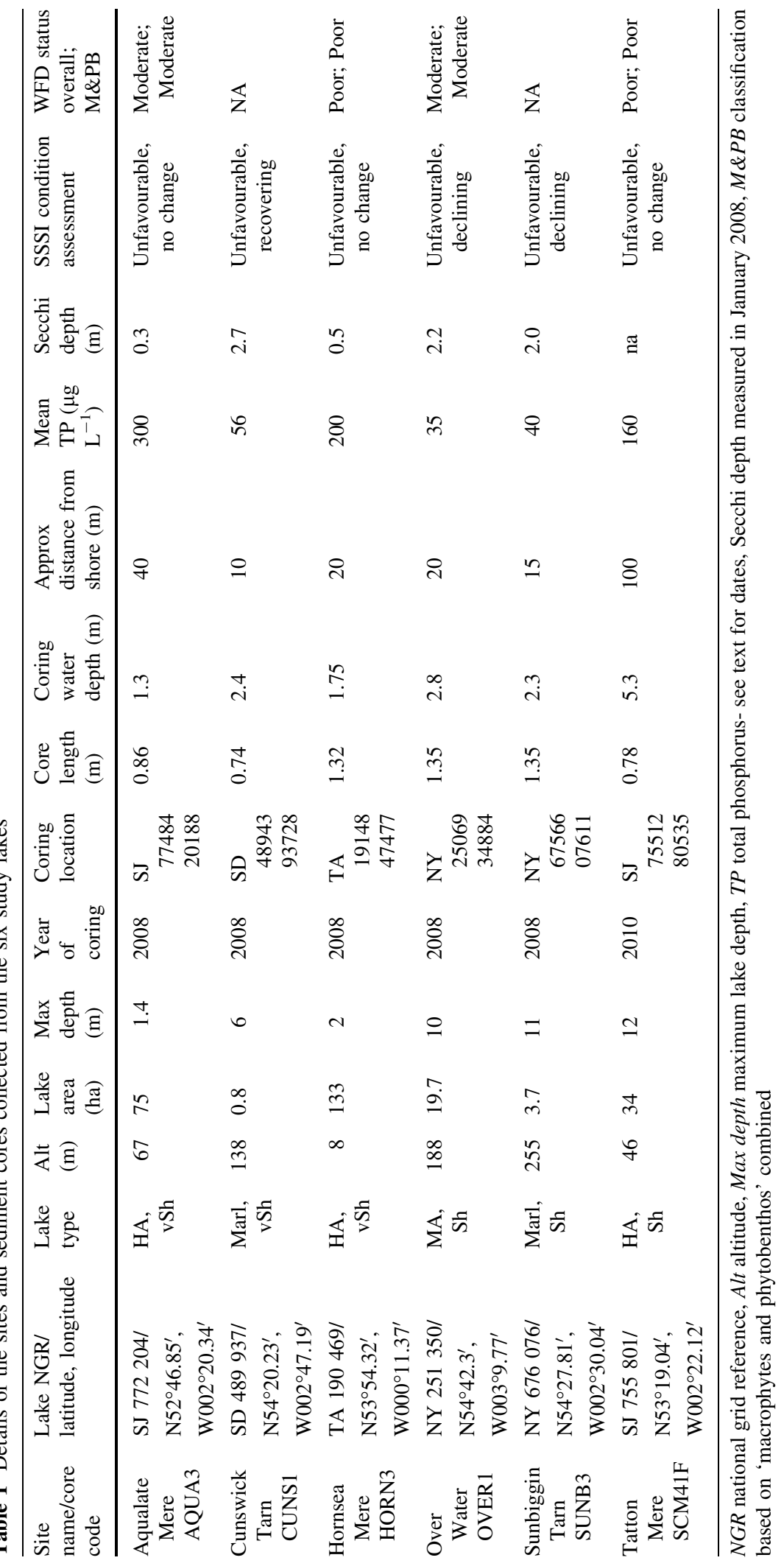


and Elodea canadensis Michx. (Wiik et al. 2014). The purpose of this work was to attempt to reconstruct the plant community of the tarn prior to any anthropogenic enrichment and hence determine reference conditions and lake type. A subsequent and more detailed multiproxy palaeoecological study was undertaken on Cunswick Tarn revealing community shifts across a range of biological groups, initially in the 1890s associated with drainage of the lake and land improvement in the catchment, followed by abrupt ecosystem shifts in the 1920s-1930s, and more recently in the 1990s when the lake changed into its current condition of low macrophyte diversity and predominance of nutrient-tolerant taxa (Wiik et al. 2015).

Hornsea Mere, Yorkshire, is a high alkalinity lake and the largest freshwater lake in the county. It was first designated as a SSSI in 1951 and is considered of national importance for wintering and breeding birds and as an example of a large, shallow, naturally eutrophic lake. The Mere is a relic of a once extensive series of lakes and marshes in the area. Whilst the Mere continues to support a range of eutrophic aquatic plant species there are signs that the site has suffered from nutrient enrichment and periodic cyanobacterial blooms occur. Recent annual mean TP concentrations of $\sim 200 \mu \mathrm{g} \mathrm{L}^{-1}$ (UK Environment Agency data for 2010-2014 unpublished) indicate that the lake is highly productive. It is hypothesised that the shallow nature of the mere and its exposed aspect make it vulnerable to recycling of nutrients from the sediments. Some progress has been made in reducing point sources of nutrients to the lake and the catchment is currently included in the England Catchment Sensitive Farming Delivery Initiative aimed at tackling diffuse nutrient inputs. Preservation problems have limited the value of previous palaeolimnological work using fossil diatoms (Bennion unpublished). A macrofossil approach was considered likely to yield an alternative record of past changes in the mere and help determine restoration targets.

Over Water, Cumbria, is a medium alkalinity, mesotrophic lake, with annual mean TP concentrations of 30-40 $\mathrm{g} \mathrm{L} \mathrm{L}^{-1}$ (Environment Agency data for 2005 unpublished). At the time of designation as SSSI the lake supported a species-rich mesotrophic flora including six pondweeds (Potamogeton spp.), Elatine hexandra (Lapierre) DC., as well as isoetid species [Isoetes lacustris L., Littorella uniflora (L.) Asch] more characteristic of oligotrophic conditions. In recent years there has been some concern about a loss of species diversity and the impact of extensive waterlevel draw-down during summer months. The open water area was artificially increased through the construction of a retaining dam in the early twentieth century. Water is now regularly abstracted from Over Water to supplement levels in a neighbouring reservoir. The palaeolimnological work was instigated to look at the long term changes at the site and in particular to look at whether there was a signal of gradual nutrient enrichment which may have affected the plant community.

Sunbiggin Tarn, Cumbria, is a small upland tarn situated on carboniferous limestone and is classified as a marl lake. The tarn is included in Sunbiggin Tarn and Moors and Little Asby Scar SSSI and is designated as a SAC under the EC Habitats and Species Directive as an example of habitat 3140 'hard oligo-mesotrophic waters with benthic vegetation of Chara spp.'. Recent water chemistry data suggest that the site is moderately productive with annual mean $\mathrm{TP}$ of $\sim 40 \mu \mathrm{g} \mathrm{L}^{-1}$, SRP of $<10 \mu \mathrm{g} \mathrm{L}^{-1}$ and chlorophyll $a$ of $<7 \mu \mathrm{g} \mathrm{L}^{-1}$ (Goldsmith et al. 2003; Environment Agency data for 2004 unpublished). The site has been the subject of a number of studies and there is a general consensus that the macrophyte community of the site has declined as a result of nutrient enrichment and/or sedimentation (Goldsmith et al. 2003). The tarn supported 25,000 breeding pairs of black-headed gulls in the 1980s and there have been concerns over the possible effects of these on the nutrient status of the site although gull numbers are now negligible. It was considered that plant macrofossils might shed further light on past plant communities.

Tatton Mere, Cheshire, is a high alkalinity, relatively large kettle-hole lake designated as a SSSI in 1963, as one of the best examples of the Midlands meres with moderate fertility and a rich and well developed aquatic flora including an extensive community of submerged macrophytes. The national target for TP for a lake of this type is an annual mean of $50 \mu \mathrm{g} \mathrm{L}^{-1}$ but the mean TP for Tatton Mere was $160 \mu \mathrm{g} \mathrm{L}^{-1}$ in 2005-2009 giving cause for concern regarding nutrient pressures. The formation and geology of the Meres results in naturally high levels of $\mathrm{P}$ (Reynolds and Sinker 1976) and low N relative to $P$ (Moss et al. 1994). This scenario has been implicated in a long history of blue-green algal blooms (McGowan et al. 1999) and complicates understanding 
of reference conditions and nutrient enrichment (Anderson 1995; Brooks et al. 2001; Fisher et al. 2009). As a result Tatton Mere does not sit easily within favourable condition tables and the aim of the palaeoecological work was to gain a greater understanding of historic plant communities to provide an effective baseline by which to monitor the condition of the Mere.

\section{Methods}

Core collection and lithostratigraphy

A single sediment core was collected using a widediameter $(\sim 8 \mathrm{~cm})$ Livingstone type piston coring device during the period 14-21 January 2008 for all sites except Tatton Mere where a Livingstone core was collected on 16 February 2010. The cores varied in length from 0.74 to $1.35 \mathrm{~m}$ and were expected to represent approximately the last 150-200 years, thereby extending back to reference conditions. Unlike microfossils such as diatom frustules which can generally be assumed to focus towards the deeper parts of a lake, plant macrofossils tend to accumulate close to their origin and thus cores for macrofossil analysis are best taken from the littoral zone of a sheltered bay, preferably at a point towards the windward shore where plant remains are most likely to accumulate (Birks 1980; Zhao et al. 2006). Expert judgement and any previous data on sediment distribution were used to decide on optimal coring locations that maximised the likelihood of finding abundant plant macrofossils. All cores were taken from shallow water areas $<100 \mathrm{~m}$ distance from the shore (Table 1). Cores were extruded in the field or the laboratory at 1-cm intervals to provide a resolution of approximately a few years per sample, and any visible stratigraphic changes were noted. The percentage dry weight, loss on ignition and carbonate content were calculated using standard techniques (Heiri et al. 2001) on selected sub-samples from each core (data not shown).

\section{SCP analysis and dating}

Dating of the cores was carried out using spheroidal carbonaceous particle (SCP) analysis (Rose 1994).
Dried sediment was subjected to sequential chemical attack by mineral acids to remove unwanted fractions and a known fraction of the resulting suspension was evaporated onto a coverslip and mounted onto a microscope slide. The number of SCPs was counted using a light microscope at $400 \times$ magnification. Criteria for SCP identification followed Rose (2008). Analytical blanks and SCP reference material (Rose 2008) were included in each batch of sample digestions and reference concentrations agreed with expected values. The detection limit for the technique is $\sim 100 \mathrm{~g} \mathrm{DM}^{-1}$ and concentrations have an accuracy of $\sim \pm 45 \mathrm{~g} \mathrm{DM}^{-1}$. The dating of the cores followed the method described in Rose et al. (1995) whereby three main features of the SCP profile (start of the record; rapid increase in concentration and subsurface peak concentration) are used to provide dates. Regional SCP dates were calibrated to sediment profiles previously dated using radiometric techniques (Rose and Appleby 2005).

\section{Macrofossil analysis}

For the macrofossil analysis, five levels were examined in the cores from all sites except for Tatton Mere where ten samples were analysed owing to the higher resolution required by Natural England. While five samples provides a relatively low analytical resolution, it was considered sufficient to characterise reference plant communities and to detect major shifts over time. An accurately measured volume of sediment $\left(\sim 30 \mathrm{~cm}^{3}\right)$ was analysed for each level. Samples were sieved at 350 and $125 \mu \mathrm{m}$ and residues from each were transferred using distilled water to plastic vials for storage. The entire residue from the 350-micron sieve was examined under a stereomicroscope at magnifications of $10-40 \times$ and plant macrofossils consisting of seeds, fruiting bodies, oospores, turions, leaves, spines and astrosclereids (star-shaped leaf cells of Nymphaeaceae) were identified and enumerated with reference to herbarium material held at the Environmental Change Research Centre, University College London. While not the focus of this paper, animal macrofossils in the form of zooplankton ephippia were also identified and enumerated alongside the plant macrofossils. Zooplankton remains can be used to infer changes in fish population density and shifts in habitat structure (Jeppesen et al. 1996, 2001; 
Davidson et al. 2007) as well as changes in macrophyte density with nutrient enrichment (Davidson et al. 2010). Given their intermediate and important position in the food-web, zooplankton data complement the plant macrofossil records and hence are reported briefly here. A quantitative sub-sample, approximately one-fifth of the sample from the 125-micron sieve, was analysed for smaller remains such as leaf spines. It was not always possible to ascribe remains to species level, thus in some cases an aggregate group of species corresponding to the highest possible taxonomic resolution was used. For example, Potamogeton pusillus agg. includes remains of $P$. pusillus L. and Potamogeton berchtoldii Fieber, and for charophyte oospores Chara vulgaris type includes $C$. vulgaris L. and Chara contraria A. Braun ex Kütz, whilst Chara aspera type includes $C$. aspera Dethard. ex Willd, Chara curta Nolte ex Kütz. and Chara virgata Kütz. The data are presented as numbers of remains per $100 \mathrm{~cm}^{3}$ of wet sediment and were plotted as stratigraphic diagrams using $\mathrm{C} 2$ (Juggins 2003).

\section{Results}

Dating

SCP data and profiles, together with detailed descriptions of the dating of individual cores, are provided in Electronic Supplementary Material. Depth/age plots of the chronologies used throughout this paper are provided in ESM1 and data are presented in ESM2. Briefly, core chronologies were produced over a range of time-scales from $68 \pm 10$ years (AQUA3) to over $150 \pm 25$ years (CUNS1; SCM41F). Limitations to the length of derived chronologies for some cores (AQUA3; HORN3; OVER1; SUNB3) were due to truncation of the SCP record by rapid sediment accumulation rates which diluted SCP concentrations to below the limit of detection.

Macrofossil analysis

\section{Aqualate Mere}

A total of 24 different aquatic plant remain types and 8 submerged plant species were recorded (Fig. 2). The two lower samples were dominated by terrestrial mosses, Juncus spp. and Typha spp. (data not shown) although Chara and Nitella oospores were present at low densities (20 and 40 per $100 \mathrm{~cm}^{3}$, respectively). The aquatic species diversity increased in the early 1900s (above $50 \mathrm{~cm}$ ) with Chara and Nitella spp. dominating, and remains of Ranunculus sect Batrachium, Potamogeton crispus L., Myriophyllum spicatum L. and Zannichellia palustris L. were also found. Juncus sp., terrestrial mosses and Gloeotrichia spp., a blue-green alga, were still prevalent in the upper levels. However, the abundance of charophytes declined in the uppermost samples (from 1960) whilst Z. palustris seeds increased. Zooplankton ephippial remains were scarce at the base of the core with relatively low numbers of Simocephalus spp., Daphnia pulex agg. Leydig and Daphnia hyalina agg. Leydig. Above $30 \mathrm{~cm}$, from the mid-1950s, Leydigia spp. and Alona spp. started to appear in larger numbers. The surface sample had the most abundant and diverse remains, with very high abundance of $D$. hyalina agg. and the large-bodied pelagic species Daphnia magna agg. Straus present in relatively high numbers.

\section{Cunswick Tarn}

A total of 20 different remain types of aquatic plants were observed in the core with 9 submerged taxa and the floating leaved Nymphaeaceae represented (Fig. 3). Characeae dominated the lower two samples (pre 1900). Five types of charophyte oospore were identified. C. vulgaris 'type' dominated the $70 \mathrm{~cm}$ sample but small numbers of $C$. rudis 'type' and $C$. aspera 'type' were also found. In the $35 \mathrm{~cm}$ sample, $C$. rudis 'type' oospores dominated and $C$. globularis 'type' was also abundant. Additionally, C. aspera 'type' was present and one oospore was identified as C. aculeolata 'type'. The only other plant remains found in the lower core were Potamogeton cf. praelongus seeds. In the upper three samples (from 1940) Chara oospores became scarce and the record was dominated by Nymphaeaceae astrosclereids. Potamogeton species were still present and Callitriche seeds were found in the surface sample. Zooplankton ephippial remains were scarce in the lower core with few remains found in the 40 and $70 \mathrm{~cm}$ samples. $D$. hyalina agg. and Ceriodaphnia spp. first appeared in the record at $35 \mathrm{~cm}(\sim 1875)$ and their abundances increased towards the top of the core. D. hyalina agg. 


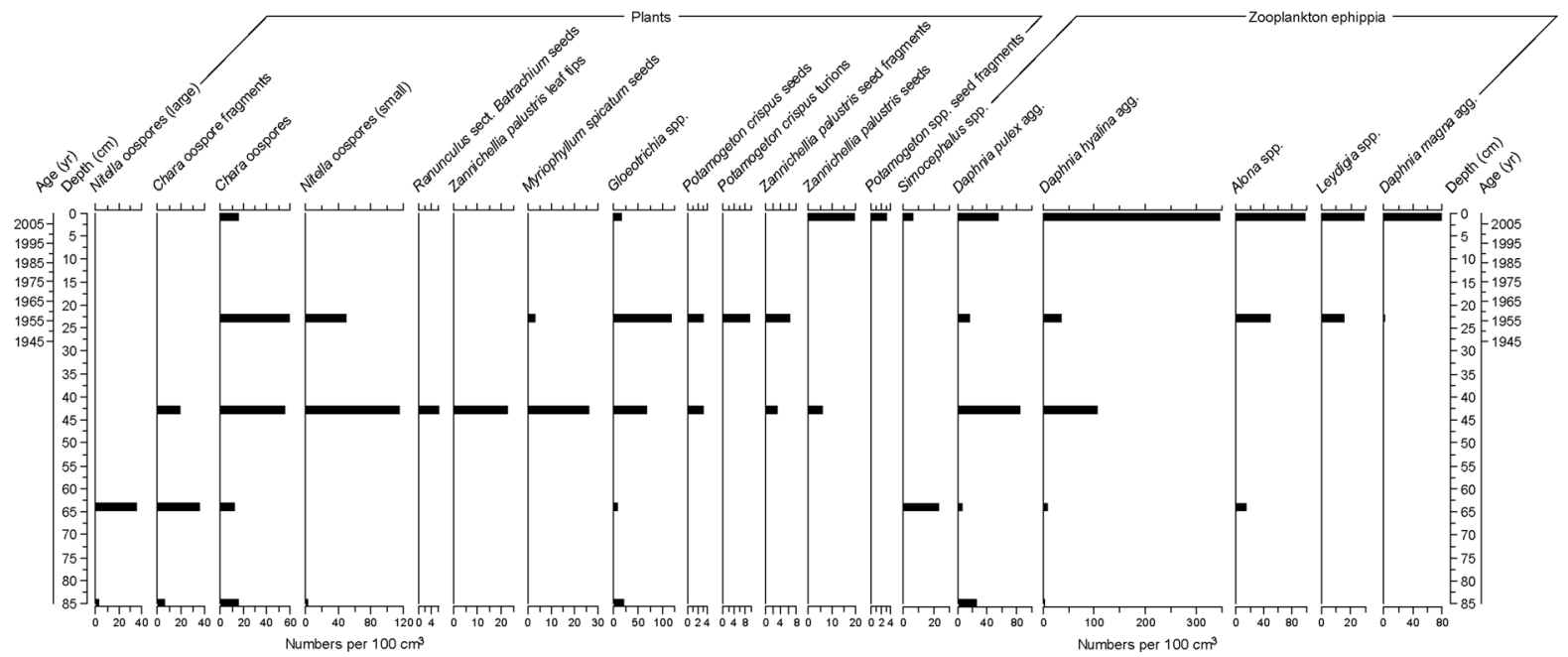

Fig. 2 Summary aquatic macrofossil stratigraphy for Aqualate Mere. Note the different scaling of the x-axes

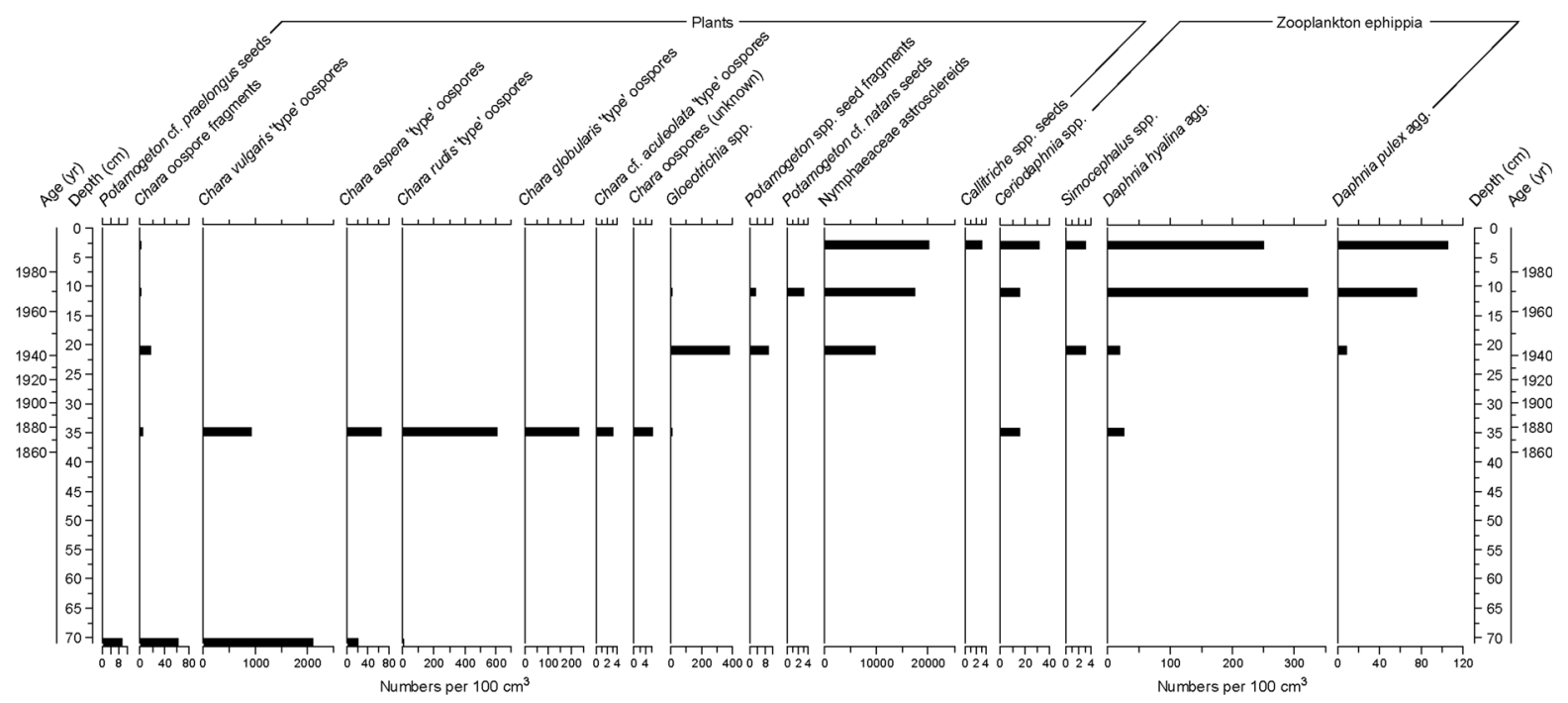

Fig. 3 Summary aquatic macrofossil stratigraphy for Cunswick Tarn. Note the different scaling of the x-axes

was the dominant species in the upper core but the large-bodied $D$. pulex agg., a pelagic species, was also abundant and Simocephalus spp., associated with plant beds, was recorded in low numbers.

\section{Hornsea Mere}

A total of nine different remain types of aquatic plants were observed in the core with four submerged taxa represented (Fig. 4). The lower two samples (pre-1920) were dominated by Chara oospores. Z. palustris appeared in the record at $41 \mathrm{~cm}$, when the numbers of Chara oospores started to decline. Above $35 \mathrm{~cm}$ (post $\sim 1920$ ) there was a shift to a species assemblage composed of more nutrient-tolerant fineleaved Potamogeton taxa and Z. palustris. Ceriodaphnia spp. were the dominant taxa in the zooplankton ephippial record at the bottom of the core with $D$. hyalina agg. also abundant (pre-1960). In the upper core (post-1960) Ceriodaphnia spp. abundance declined, whilst the number of D.hyalina agg. remains increased along with $D$. pulex agg. and $D$. 


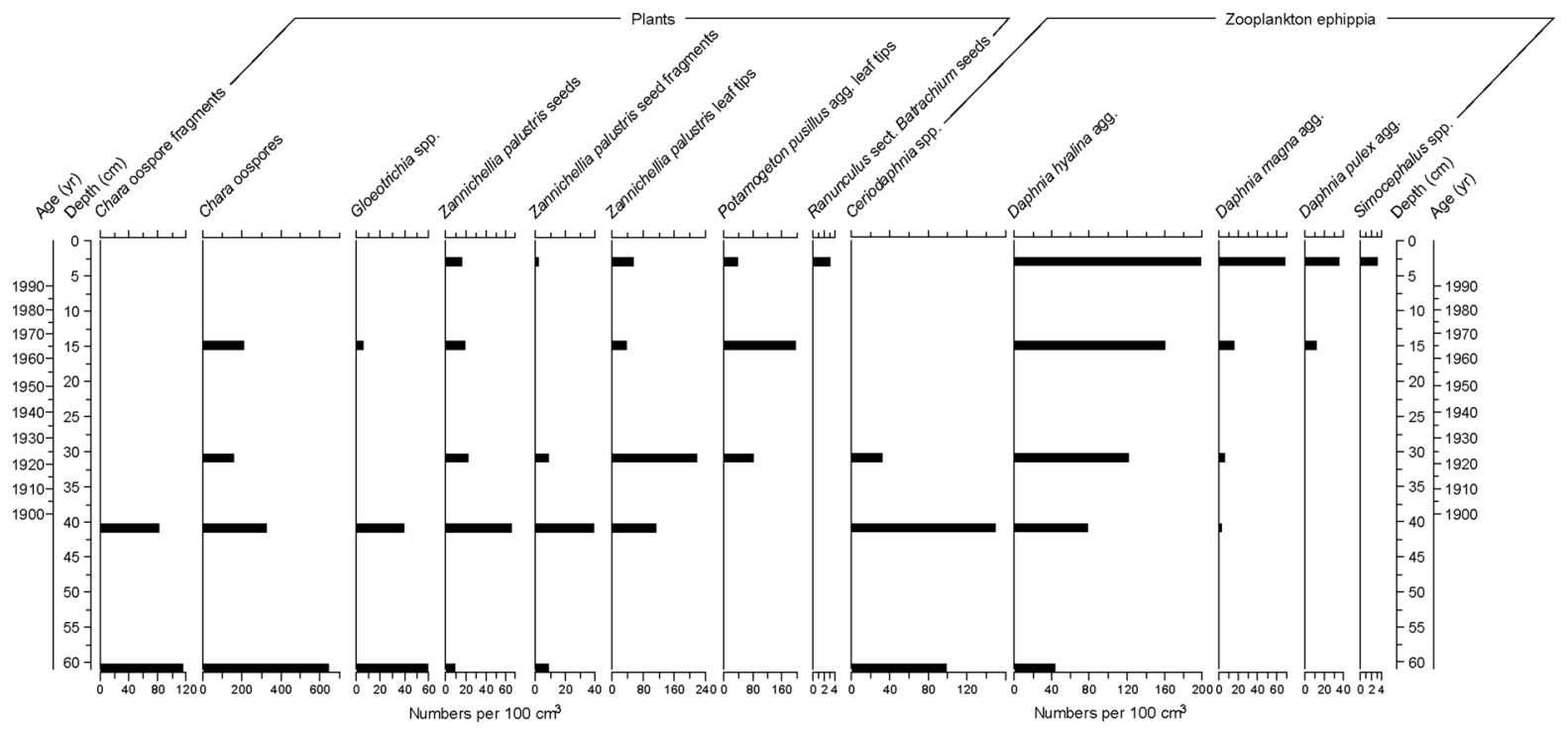

Fig. 4 Summary aquatic macrofossil stratigraphy for Hornsea Mere. Note the different scaling of the x-axes

magna agg., and Simocephalus spp. was also present. Daphnia spp. were the dominant taxa from the 1960 s to the present day.

\section{Over Water}

A total of 23 different remain types of aquatic plants were observed in the core with 8 submerged taxa represented (Fig. 5). The lowermost sample was characterised by Chara, Nitella and I. lacustris, the latter dominating. There were no aquatic plant remains in the $70 \mathrm{~cm}$ sample. In the upper core (from 1920) Nitella and I. lacustris remains disappeared. Chara oospores were still present but the aquatic species assemblage shifted towards one comprised of fineleaved Potamogeton spp., Callitriche and M. spicatum in the upper part of the record. Ephippial remains were scarce in the lower core (pre $~ 1950$ ) with dominance by $D$. hyalina agg. In the upper two samples (from 1950) D. hyalina agg. continued to dominate but the remains of pelagic species were considerably more abundant and included D. pulex agg. and Ceriodaphnia spp.

\section{Sunbiggin Tarn}

A total of 24 different remain types of aquatic plants were observed in the core with 8 submerged taxa represented (Fig. 6). The lower core (pre-1950) was dominated by terrestrial mosses and Juncus seeds (not shown). Chara oospores first appeared in the record at $97 \mathrm{~cm}(\sim 1900)$ and were most abundant in the $30 \mathrm{~cm}$ sample $(\sim 1982)$ although at relatively low abundances. Three types of charophyte oospore were identified, namely $C$. vulgaris 'type', $C$. rudis 'type' and $C$. aspera 'type'. Myriophyllum leaf tips and Nitella sp. oospores were also recorded in the lower part of the record. In the $65-\mathrm{cm}$ sample only (mid1940s) P. crispus turions were abundant. In the two upper samples (post- 1980) Z. palustris arrived. Other remains in the upper core included Nitella oospores and Callitriche spp. but Chara oospores were notably absent from the surface sample. Terrestrial mosses, Juncus seeds and Cyperaceae were still relatively abundant, although in lower numbers than in the lower samples (not shown). Chydorus sphaericus O.F.Müller, a littoral-benthic species, dominated the ephippia record in the lower core (pre-1950) while Simocephalus spp. was also present. In the upper part of the record (from $\sim 1982$ ) the remains of $C$. sphaericus were no longer present and the numbers of pelagic species, D. hyalina agg. and D. pulex agg., increased markedly, peaking in the $30 \mathrm{~cm}$ sample. Ephippial remains in the surface sample were scarce.

\section{Tatton Mere}

A total of 28 different remain types of aquatic plants were observed in the core with 13 submerged taxa, 


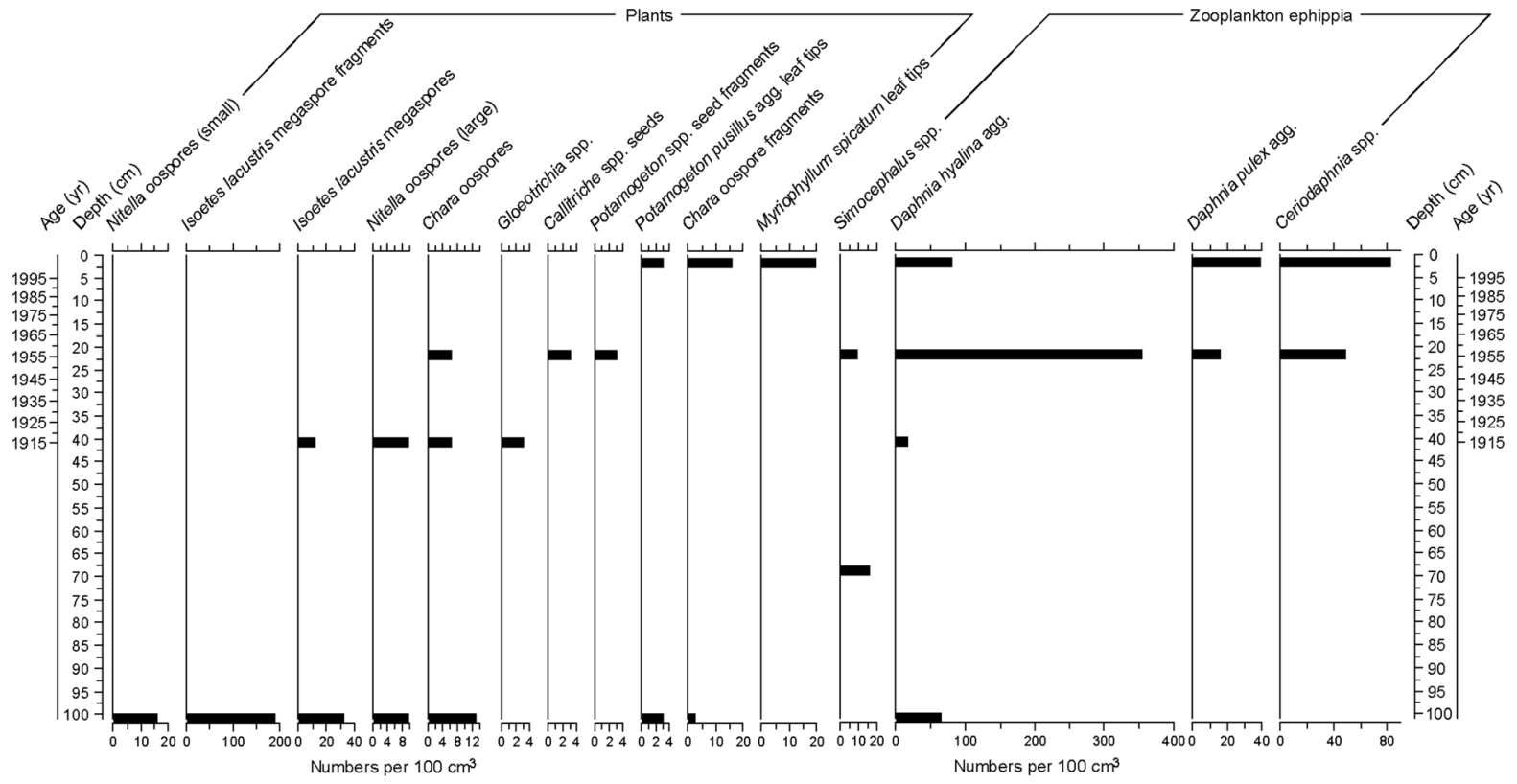

Fig. 5 Summary aquatic macrofossil stratigraphy for Over Water. Note the different scaling of the x-axes

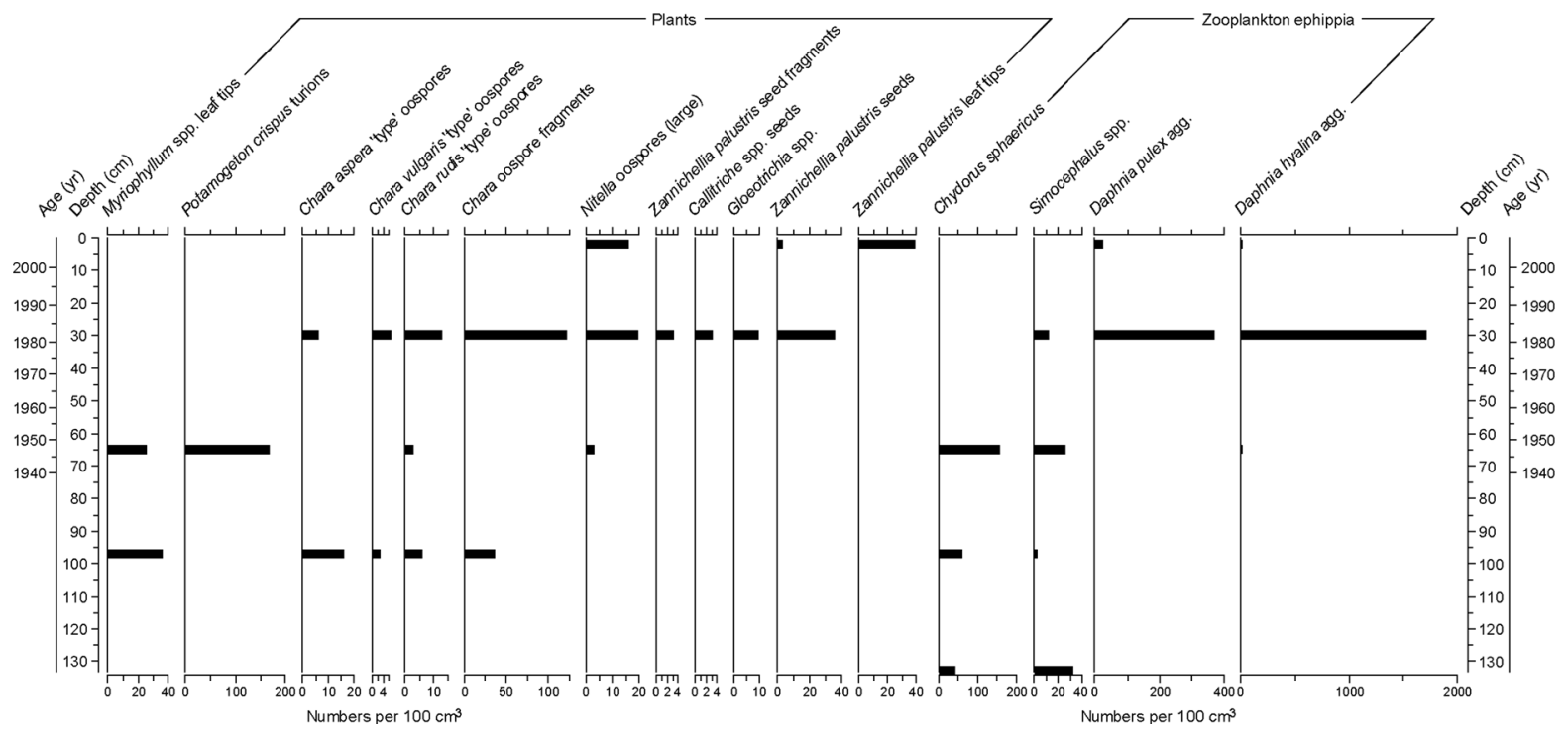

Fig. 6 Summary aquatic macrofossil stratigraphy for Sunbiggin Tarn. Note the different scaling of the x-axes

several emergent taxa and the floating leaved Nymphaeaceae represented (Fig. 7a). The section 70-55 cm ( $\sim$ pre-1800) contained Nymphaea alba L. seeds and seed fragments, and Nymphaeaceae astrosclereids. Menyanthes trifoliata L. seeds, Carex seeds and $R$. sect. Batrachium seed fragments were also present. Two Chara oospore types which could not be assigned a name were represented, with Chara spp. (oval) oospores reaching relatively high numbers in the bottom sample (285 oospores per $100 \mathrm{~cm}^{3}$ ). Two Potamogeton seed types were also identified in the lower core (P. cf. natans and P. obtusifolius Mert. $\&$ W. D. J. Koch) with some fine-leaved Potamogeton leaf fragments also present. In the section $55-15 \mathrm{~cm}$ 

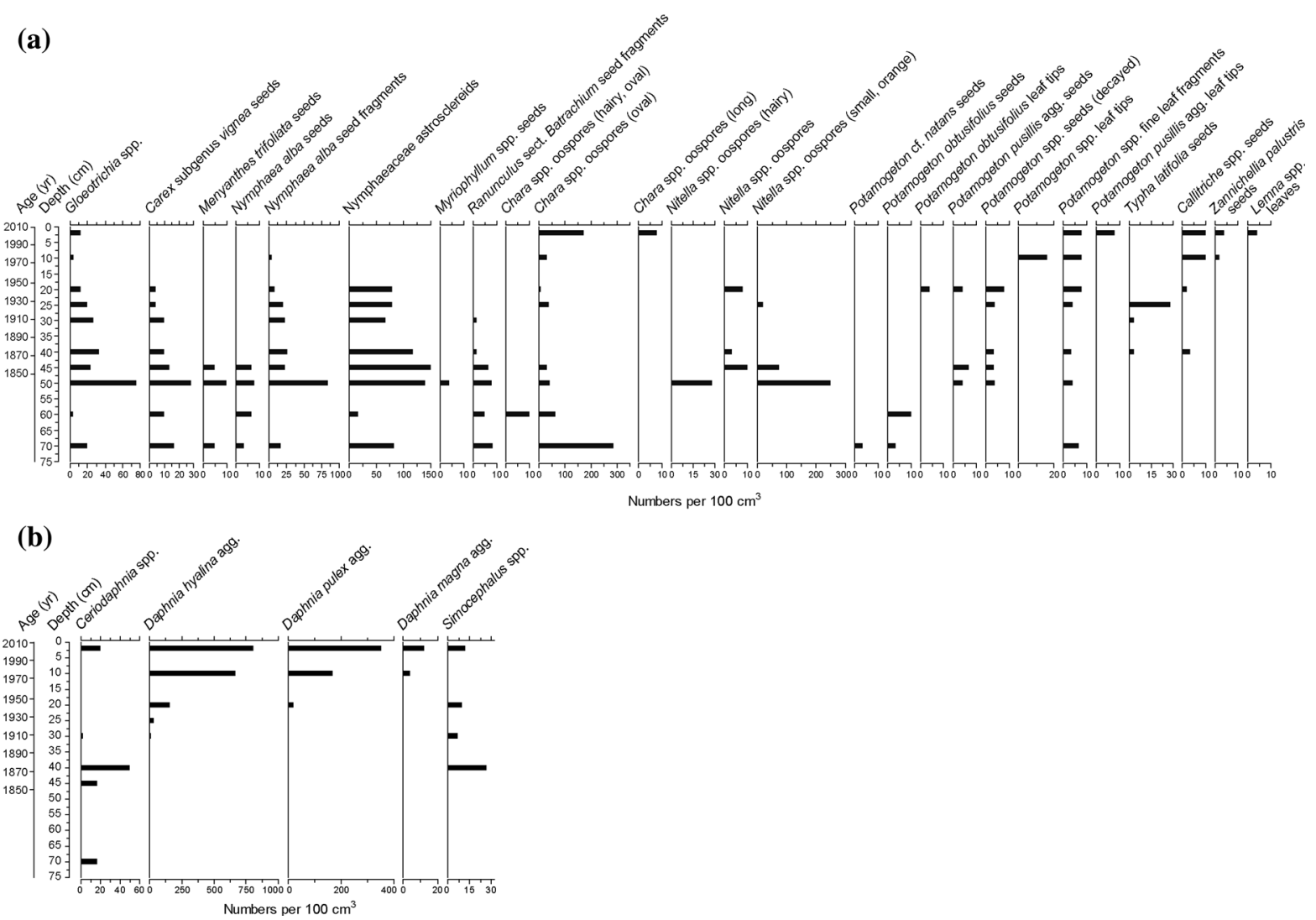

Fig. 7 Summary aquatic macrofossil stratigraphy for Tatton Mere: a plants, b zooplankton ephippia. Note the different scaling of the $\mathrm{X}$-axes

$(\sim 1800-1960)$ aquatic species diversity reached a maximum with 16 remain types observed in the $50 \mathrm{~cm}$ sample. Gloeotrichia spp. M. trifoliata seeds, Carex spp, seeds, $R$. sect. Batrachium seed fragments, $N$. alba seeds and seed fragments, and Nymphaeaceae astrosclereids were all present but decreased towards the upper part of this section. Myriophyllum seeds and Nitella spp. oospores were also present in the lowermost samples of this part of the core but absent from the rest of the record. Two other Nitella oospore types occurred in the 55-15 cm section, but Chara oospores were relatively scarce throughout the mid-section of the core. P. obtusifolius leaf tips, P. pusillis agg. seeds, fine-leaved Potamogeton leaf fragments and unidentified decayed Potamogeton seeds were also present within this mid-section. The upper part of the core from 15 to $0 \mathrm{~cm}(\sim 1960-2010)$ comprised two samples and contained fewer macrofossil remains than the rest of the core. Chara oospores ('oval' type) were present in both samples but increased in the uppermost sample to 172 oospores per $100 \mathrm{~cm}^{3}$. Chara oospores ('long' type) occurred in the uppermost sample only. In contrast no Nitella oospores were found within the uppermost samples. Potamogeton fine-leaved fragments, $P$. pusillis agg. leaf tips, Callitriche seeds and Z. palustris seeds were present throughout the two upper samples. Ephippial remains were scarce at the base with relatively low numbers of Ceriodaphnia spp. occurring at $70 \mathrm{~cm}$. Both Ceriodaphnia and Simocephalus spp. numbers increased by the $40 \mathrm{~cm}$ sample $(\sim 1880)$. In the section 35-0 cm ( 1890-2010) ephippial species diversity increased. Abundances of $D$. hyalina agg., $D$. pulex agg. and the large-bodied pelagic species $D$. magna agg. increased dramatically in the upper core samples (post-1960), with Ceriodaphnia and Simocephalus spp. occurring in low numbers in the uppermost sample. 


\section{Discussion}

Reference plant communities

Cautious extrapolation of the chronologies derived from the SCP profiles indicate that the cores from all six sites span approximately the last $150-200$ years thereby affording the opportunity to examine the plant communities on a temporal scale extending back to at least $1850 \mathrm{AD}$, a period prior to major industrialisation and agricultural intensification and hence generally considered to represent pre-impact conditions for many UK lakes (Bennion et al. 2011). Thus, while there are examples of lakes that first began to be enriched by human activity many centuries and even millennia ago (Bradshaw et al. 2005), the lowermost samples in our sediment cores can likely be used to define reference conditions for aquatic plants for individual lakes and also particular lake types. Indeed the possibility of deriving reference conditions for high alkalinity, shallow lakes using palaeoecological techniques is an especially welcome one given that few, if any, undisturbed examples of this lake type occur in the UK and they are rare throughout most of Europe. With the exception of Over Water, where no remains were found in one of the lower core samples, reference conditions are described here for the study lakes based on at least two samples.

For the high-alkalinity lakes (Aqualate, Hornsea, and Tatton Meres), the macrofossil data suggest that all three lakes supported charophytes in the past, taxa characteristic of this lake type in favourable condition (IAFG 2015). Aqualate Mere formerly supported both Chara and Nitella taxa, Hornsea Mere was formerly dominated by Chara spp., and at Tatton Mere several Chara taxa were present. At Tatton Mere the aquatic macrophyte flora was structurally diverse in the early period of the core comprising several other taxa associated with lakes of moderate productivity such as M. trifoliata, Myriophyllum spp., R. sect. Batrachium, $P$. cf. natans and P. obtusifolius. This suggests that this lake was relatively nutrient-rich even before 1850 . Over Water is classified as a medium rather than high alkalinity lake and accordingly the plant macrofossil data indicate that this site formerly supported $I$. lacustris, a species typically associated with relatively unproductive soft water lakes (Rørslett and Brettum 1989), in addition to Nitella spp. and Chara spp.
For the two marl lakes (Sunbiggin and Cunswick Tarns), the plant macrofossil data indicate that both supported diverse charophyte communities in the past. Abundant charophyte beds are a characteristic of favourable conditions in marl lakes according to current assessment criteria (Wiik et al. 2014; IAFG 2015). Prior to $\sim 1900$, the macrofossils suggest that at least five charophyte taxa were present in Cunswick Tarn. This agrees with early plant records for the site that indicate that the flora was typical of a mesotrophic, calcareous (marl) lake (Group I in the 'Vegetation communities of British lakes', Duigan et al. 2007). Various surveys reported occurrence of Chara aculeolata Kütz., Chara globularis agg. and $C$. curta in $\sim 1900$. However, interestingly, the oospore types found in the $35 \mathrm{~cm}$ sample $(\sim 1875)$ are different to those in the lowermost sample which may reflect a shift in the charophyte flora to a more calcareous system at some time in the late nineteenth century. For example, $C$. vulgaris 'type' was found at the base of the core where carbonate content was low whilst $C$. rudis 'type' and $C$. cf. aculeolata 'type', taxa typically associated with base-rich conditions, were found at $35 \mathrm{~cm}$ which coincides with high carbonate content in the $30-40 \mathrm{~cm}$ section of the core. This could represent either localised marl precipitation around the plant beds themselves or possibly lake wide precipitation of marl (Wiik et al. 2015). The plant macrofossil data indicate that Sunbiggin Tarn formerly supported at least three Chara types and Nitella spp., as well as elodeids, including Myriophyllum sp. (probably M. spicatum) and P. crispus.

Similar macrophyte assemblages to those indicated by the plant macrofossils in the lower core sections of the study sites, with charophytes as a key component, have been recorded in the pre-enrichment period of other north European shallow lakes (Odgaard et al. 1997; Davidson et al. 2005; Sayer et al. 2010a). Plant macrofossil records suggest that a diverse community of submerged aquatic vegetation was formerly present in highly alkaline, shallow lakes with typically Myriophyllum spp., Potamogeton spp. and several species of Characeae, as well as floating-leaved Nymphaeaceae in some cases (here seen only in Tatton Mere). This accords well with the current macrophyte flora characteristic of high alkalinity, shallow lakes in the UK that are classified as high ecological status (Willby et al. 2009). An important feature of charophytes is a capacity for over-wintering 
and persisting through the growing season in temperate climates (Blindow 1992; Fernández-Aláez et al. 2002) and it is likely, therefore, that the seasonal duration of plant coverage would have been near yearround in the past (Sayer et al. 2010c). This long period of plant dominance can limit the nutrients available to phytoplankton likely resulting in high water clarity and a predominance of benthic primary production in shallow lakes (van den Berg et al. 1998).

\section{Floristic change}

The macrofossil records indicate that the aquatic vegetation of all six sites has undergone considerable change over the last 150-200 years with a general shift towards species more typically associated with eutrophic conditions. Floristic changes similar to those recorded in the studied cores have been observed in the sediment records of several other English lakes (Davidson et al. 2005; Sayer et al. 2010b) and in long-term studies (Blindow 1992). A common feature is the decline in abundance of charophytes and an increase in fine-leaved Potamogeton taxa, Z. palustris and occasionally Callitriche spp. over time. Specifically, the changes recorded in the two marl lakes are consistent with macrophyte community changes in other marl lakes following eutrophication where a transition from Chara species dominance to a more mixed community with fewer charophytes, and including species such as E. canadensis, Z. palustris, $P$. crispus, and Ranunculus circinatus Sibthorp, is typically seen (Wiik et al. 2013). These shifts are consistent with eutrophication where tall canopyforming angiosperms such as Potamogeton spp. have a competitive advantage over lower growing Characeae (Blindow 1992; Brodersen et al. 2001; Kolada et al. 2014). Charophyte oospores are present in the uppermost sample of the sediment records of all our study lakes with the exception of Hornsea Mere (where they were lost from the record at some time since the mid1960s), yet their numbers are much reduced compared with the lower core sections. This pattern supports findings elsewhere where charophytes still occur in eutrophic waters but are typically out-competed by more nutrient-tolerant species as lakes become enriched and light availability is reduced, with charophytes often becoming restricted to areas of shallow water (Blindow 1992; van den Berg 1999; van Nes et al. 2002). The erect, canopy-forming angiosperms are better adapted to low light conditions via mechanisms such as shoot elongation to maximise photosynthesis and to shading via high spring growth rates made possible by storage of carbohydrates in large buds and turions (Blindow 1992). The transition from charophyte to fine-leaved Potamogeton-Zannichellia dominance, when combined with elevated nutrient levels, has implications for the duration of the plant covered period as fine-leaved pondweeds tend to crash by late summer in eutrophic shallow lakes thereby opening up opportunities for phytoplankton to dominate over autumn and winter (Sayer et al. 2010c). At Over Water I. lacustris was lost from the sediment record between 1920 and 1950, coincident with initial changes in the diatom assemblages (Bennion et al. 2009). The shift from slower-growing isoetid species to tall-growing elodeids has been reported for other soft-water lakes in association with nutrient enrichment (Roelofs 1983; Smolders et al. 2002).

The abundance of planktonic Cladocera taxa recorded in the ephippia data, especially Daphnia spp., markedly increased in all six sites at the same time as shifts were seen in the plant macrofossil stratigraphies, suggesting a pronounced increase in pelagic primary production and/or low grazing pressure from zooplanktivorous fish (Davidson et al. 2011). Cunswick Tarn is a fishless lake and therefore the Daphnia increases seen in the core from this site are undoubtedly driven by increased nutrient availability (Wiik et al. 2015). The combined evidence from the plant and animal macrofossils clearly points towards progressive enrichment of the lakes. At Aqualate Mere, the timing of the initial decrease in charophyte remains is coincident with a change in the sediments from an organic, fine lake mud to an inorganic silt-clay (at $\sim 30 \mathrm{~cm}$; 1940). This boundary is recorded across the lake (Hutchinson 2005) and most likely reflects in-wash from catchment activities such as parkland landscaping, installation of drainage systems and sediment erosion from agriculture (Pittam et al. 2009). Therefore, at Aqualate Mere the observed changes in the plant macrofossil record have most likely resulted from a combination of enrichment of the lake and enhanced sedimentation.

The list of species recorded by the plant macrofossil data in the uppermost samples of the cores accords well with contemporary macrophyte survey data for the lakes suggesting, as in previous studies (Davidson et al. 2005; Salgado et al. 2010; Clarke et al. 2014; 
Levi et al. 2014), that plant macrofossils faithfully capture the main components of the aquatic flora. In Aqualate Mere recent surveys record Z. palustris as the dominant species with presence of $P$. crispus and $P$. pectinatus, as suggested by the macrofossils. At Hornsea Mere, Z. palustris and $P$. pusillus are recorded as abundant, in good agreement with the macrofossil data. At Tatton Mere, Callitriche spp., Chara spp., Lemna spp., P. berchtoldii and other fineleaved pondweeds (e.g. P. crispus, $P$. pectinatus) and $Z$. palustris were recorded in both the contemporary survey and macrofossil data. At Cunswick Tarn, in accordance with the macrofossil data, a survey in 2004 recorded $N$. lutea as dominant and only $N$. lutea was recorded in a survey in 2005. Nonetheless the plant macrofossils did not record all species found in recent surveys. At Hornsea Mere, P. pectinatus, M. spicatum, $C$. demersum and $C$. globularis were observed in surveys but remains of these taxa were not found in the surface sediments. At Tatton Mere, the non-native species E. canadensis and Elodea nuttallii (Planch.) H. St. John were observed in the 2008 survey but were not present in the macrofossil dataset and E. canadensis and E. nuttallii now dominate the submerged community of Cunswick Tarn and Over Water, respectively, but were not observed in the surface sediments of the cores. Poor preservation of vegetative (leaf) remains and infrequent production of seeds mean that Elodea plants rarely leave identifiable remains in the sediment record (Clarke et al. 2014). This is a shortcoming of the palaeorecord as these European invasive species increasingly dominate lakes to the detriment of native taxa and a better knowledge of their arrival times and interactions with other taxa would further inform conservation. A particular limitation of the current study was the low number of samples analysed per core. While the main changes were revealed, high variability in the abundance of macrofossil remains between samples caused difficulty in interpreting the changes in any great detail and higher resolution analysis would be required for refining stories of change.

\section{Conservation implications}

The macrofossil records have allowed the pre-impact plant communities of the study sites to be defined. These data can be used to determine the macrophyte component of ecological reference conditions for
WFD classification purposes (Kolada et al. 2014) and inform the definition of favourable status for designated sites monitoring (IAFG 2015). Our findings accord with the conventional view that the initial state of unimpacted shallow lakes is defined by macrophyte-dominance and clear water conditions (Phillips et al. 2016) and the reference communities captured by the macrofossil record are typically associated with low to moderate nutrient concentrations. In their pre-impact state, all of the lakes supported macrophyte species characteristic of favourable condition for their lake type (IAFG 2015).

The compositional changes recorded by the plant macrofossils clearly have implications for ecological status and condition assessments. In lake condition assessments, the characteristic species target for 'naturally eutrophic lakes waters with Magnopotamion or Hydrocharition-type vegetation', under which the high alkalinity sites in this study fall, is for at least six characteristic species and no loss of characteristic species recorded from the site (IAFG 2015). The palaeoecological data provide clear evidence that all three of the high alkalinity study sites have lost characteristic species, namely charophytes. The palaeoecological data would therefore support the condition of these lakes as 'unfavourable'. Our findings have important implications for the conservation of marl lakes as high-quality marl lakes across Europe are increasingly rare (Pentecost 2009; Wiik et al. 2013). The characteristic species target for marl lakes, which are categorised as 'hard oligo-mesotrophic waters with benthic vegetation of Chara spp.', is for no loss of characteristic species recorded from the site. Of the two marl lakes in this study, Sunbiggin Tarn has evidently seen a decline in its charophyte community while charophytes are completely absent from Cunswick Tarn and from c. 1950 the macrofossil record indicates dominance by Nymphaeaceae. The timing is synchronous with a decline in carbonate content of the sediments, potentially signalling the cessation of marl precipitation. Indeed Cunswick Tarn currently fills none of the macrophyte criteria for marl lakes in the British Isles (diversity of Potamogeton and Chara spp., M. spicatum-Palmer et al. 1992; Duigan et al. 2007). Thus, as for the high alkalinity lakes, the macrofossil data support the condition of these lakes as 'unfavourable'. Over Water is mostly aligned to lake habitat type 'Oligotrophic to mesotrophic standing waters with vegetation of the 
Littorelletea uniflorae and/or of the Isoëto-Nanojuncetea'. Given the marked changes seen in the macrofossil record and loss of characteristic species, an assessment of 'unfavourable' condition would also seem appropriate for this site. It should be noted that Over Water, Tatton Mere and Cunswick Tarn cannot be regarded as being in 'favourable' condition due to the high frequency of the invasive, non-native Elodea species (E. canadensis, E. nuttallii) found in current surveys of these sites.

In terms of WFD classification, the palaeoecological data confirm that all of the sites have deviated more than 'slightly' from their reference plant communities and hence they fail to meet the objective of Good status for macrophytes. The current macrophyte, and indeed overall, status classification of Moderate for Aqualate Mere and Over Water, and of Poor for Hornsea Mere and Tatton Mere accords with the moderate to major deviation from reference assemblages observed in the macrofossil stratigraphies. It is difficult to distinguish between moderate and major deviation as these terms are rather subjective and there is currently no metric that can be applied to macrofossil data to quantify the degree of change. Sunbiggin and Cunswick Tarns fall below the size threshold for WFD reporting but the macrofossil records indicate that the former has undergone moderate change and the latter more substantial change. Classifications of Moderate and Poor, respectively, would therefore seem appropriate.

Each lake has its own unique history of catchment and in-lake change and thus the timing of the macrophyte shifts vary between sites. Nonetheless, all sites experienced degradation of their ecological function at some time in the early to mid-1900s. There are too few samples to pinpoint exact timing or rates of change but the changes appear to be gradual suggesting that progressive eutrophication is likely to be a key driver. In accordance with our findings, other studies of plant communities over decadal to centennial timescales have shown gradual shifts rather than rapid loss (Sand-Jensen et al. 2000; Davidson et al. 2005; Sayer et al. 2010a, 2016). Phillips et al. (2016), in their review of 40 years of macrophyte data from the Norfolk Broads, show that gradual erosion of a stable plant community usually occurs prior to complete plant loss. Therefore the shifts seen in the macrofossil data provide a warning that the lakes are potentially on a pathway to macrophyte loss if conservation measures are not taken. Furthermore, Phillips et al. (2016) highlight that the longer term stability of macrophyte dominance is reduced as the species richness declines and there is evidence of decreased diversity in the macrofossil records from the study sites. While the macrofossil data suggest marked changes and deterioration in the condition of the aquatic plant communities, importantly all sites still support plants. Clearly the over-riding conservation aim is to prevent plant loss and the possible transition to a phytoplankton-dominated lake system as seen elsewhere (Sand-Jensen et al. 2000; Körner 2002).

The evidence from shallow lake research suggests that sustained macrophyte recovery requires substantial reduction in nutrient concentrations (Jeppesen et al. 2012). The palaeoecological data strongly suggest that remedial action is needed at all six study sites and hint at the action required. A clear recommendation is that nutrient and, in some cases, sediment loads must be reduced at the sites if characteristic species are ever to return. The information on past plant communities of the lakes provided by the current study can be used to set restoration targets for the sites and to assess the degree of recovery once management is in place. The palaeoecological findings raise interesting questions about the conservation targets for Cunswick Tarn given that it has ceased to function as a marl lake. It now bears the characteristics of a high alkalinity waterbody and no longer precipitates carbonate, and hence is unlikely in the short to medium term to support the pre-impact plant communities typical of a marl lake (Wiik et al. 2015). More realistic restoration targets can, therefore, be set with this information in mind such as reduction of nutrient inputs with the target being reduction of algal biomass, improved water clarity and healthy populations of the pondweeds and nymphaeids that are present today.

While this study has focused on only six sites, there is potential for macrofossil analyses to inform the conservation plans of many more lakes. The site condition of over 100 SSSI lakes has recently been assessed (Goldsmith et al. 2012; Burgess et al. 2014) based on their current macrophyte flora and nutrient status. A total of 54 lakes were classified as being in 'unfavourable' condition due to a failure to either meet the floristic or water quality targets (or both). While most of these sites have clearly deteriorated over the past $\sim 100$ years, the extent to which they have declined in quality is often not known and hence 
restoration targets tend to be generic for the region and lake type, rather than informed from site specific records. Crucially, some sites may never have supported species deemed necessary to comply with the required targets and plant macrofossil records can provide that vital information. The case studies presented here illustrate how the ecological information contained within the sediment record can improve our knowledge of past plant community dynamics and implications for conservation. The ability to view these changes within a dated timeframe can lead to a better understanding of the causes of observed declines and hence inform future management and aid long-term recovery.

\section{Conclusions}

Aquatic plant macrofossils provide an insight not only into the past species assemblages that might have populated 'reference' communities in lakes, but also the degree to which the aquatic flora has shifted away from the relatively stable conditions prior to 1850 . This study highlights the value of the macrofossil record in the status assessment of water bodies and in informing policy issues, such as the continued need to tackle freshwater eutrophication. The macro-structure of plant remains affords visibility and this, coupled with the high value attached to aquatic plants in lake conservation, makes them a particularly attractive tool to lake managers. Furthermore, plant macrofossils have the advantage over some other sub-fossil groups commonly used in paleolimnology, (diatoms and ostracods), that the ecology of their contemporary counterparts is very well understood. Hence, reliable interpretations of the fossil data are often possible and ecologically sound information can be provided to conservationists.

Acknowledgements This work was funded by several awards from Natural England to ENSIS Ltd at the Environmental Change Research Centre, UCL. Thank you to Cath Rose for some of the SCP analysis and to Cath D'Alton for production of the figures.

Open Access This article is distributed under the terms of the Creative Commons Attribution 4.0 International License (http:// creativecommons.org/licenses/by/4.0/), which permits unrestricted use, distribution, and reproduction in any medium, provided you give appropriate credit to the original author(s) and the source, provide a link to the Creative Commons license, and indicate if changes were made.

\section{References}

Anderson NJ (1995) Naturally eutrophic lakes: reality, myth or myopia? Trends Ecol Evol 10:137-138

Ayres K, Sayer CD, Perrow M, Skeate E (2008) Palaeolimnology as a tool to inform shallow lake management: an example from Upton Great Broad, Norfolk, UK. Biodivers Conserv 17:2153-2168

Barbour MT, Swietlik WF, Jackson SK, Courtemanch DL, Davies SP, Yoder CO (2000) Measuring the attainment of biological integrity in the USA: a critical element of ecological integrity. Hydrobiologia 422(423):453-464

Bennion H, Simpson GL (2011) The use of diatom records to establish reference conditions for UK lakes subject to eutrophication. J Paleolimnol 45:469-488

Bennion H, Rawcliffe R, Burgess A, Clarke G, Davidson T, Rose C, Rose N, Sayer C, Turner S (2009) Using novel palaeolimnological techniques to define lake conservation objectives. Final Report to Natural England. Natural England Commissioned Report No. 22, Sheffield. www. naturalengland.org.uk

Bennion H, Battarbee RW, Sayer CD, Simpson GL, Davidson TA (2011) Defining reference conditions and restoration targets for lake ecosystems using palaeolimnology: a synthesis. J Paleolimnol 45:533-544

Birks HH (1980) Plant macrofossils in Quaternary lake sediments. Arch Hydrobiol 15:1-60

Birks HH (2001) Plant macrofossils. In: Smol JP, Birks HJB, Last WM (eds) Tracking environmental change using lake sediments, vol 3., Terrestrial, algal, and siliceous indicatorsKluwer Academic Publishers, Dordrecht, pp 49-74

Birks HH (2007) Plant macrofossil introduction. In: Elias SA (ed) Encyclopedia of quaternary science, vol 3. Elsevier, Amsterdam, pp 2266-2288

Blindow I (1992) Decline of charophytes during eutrophication: comparison with angiosperms. Freshw Biol 28:9-14

Bradshaw EG, Rasmussen P, Odgaard BV (2005) Mid- to lateHolocene change and lake development at Dallund $S \varnothing$, Denmark: synthesis of multiproxy data, linking land and lake. Holocene 15:1152-1162

Brodersen KP, Odgaard BV, Vestergaard O, Anderson NJ (2001) Chironomid stratigraphy in the shallow and eutrophic Lake Søbygaard, Denmark: chironomid-macrophyte co-occurrence. Freshw Biol 46:253-267

Brooks SJ, Bennion H, Birks HJB (2001) Tracing lake trophic history with a chironomid-total phosphorus inference model. Freshw Biol 46:511-532

Burgess A, Goldsmith B, Goodrich S (2014) Interpretation of water framework directive macrophyte data for CSM condition assessment. Project Ref. No. 25552. Report to Natural England. ENSIS, London

Clarke SJ, Lynch AJJ (2016) Palaeoecology to inform wetland conservation and management: some experiences and prospects. Mar Freshw Res 67:695-706

Clarke GH, Sayer CD, Turner S, Salgado J, Meis S, Patmore IR, Zhao Y (2014) Representation of aquatic vegetation change by plant macrofossils in a small and shallow freshwater lake. Veg Hist Archaeobot 23:265-276

Davidson T, Sayer C, Bennion H, David C, Rose N, Wade M (2005) A 250 year comparison of historical, macrofossil 
and pollen records of aquatic plants in a shallow lake. Freshw Biol 50:1671-1686

Davidson TA, Sayer CD, Perrow MR, Bramm M, Jeppesen E (2007) Are the controls of species composition similar for contemporary and sub-fossil cladoceran assemblages? A study of 39 shallow lakes of contrasting trophic status. J Paleolimnol 38:117-134

Davidson TA, Sayer CD, Perrow M, Bramm M, Jeppesen E (2010) The simultaneous inference of zooplanktivorous fish and macrophyte density from sub-fossil cladoceran assemblages: a multivariate regression tree approach. Freshw Biol 55:546-564

Davidson TA, Bennion H, Jeppesen E, Clarke GH, Sayer CD, Morley D, Odgaard BV, Rasmussen P, Rawcliffe R, Salgado J, Simpson GL, Amsinck SL (2011) The role of cladocerans in tracking long-term change in shallow lake trophic status. Hydrobiologia 676:299-315

DEFRA (2011) Biodiversity 2020: a strategy for England's wildlife and ecosystem services. DEFRA, London, p 45

Dixit SS, Smol JP, Charles DF, Hughes RM, Paulsen SG, Collins GB (1999) Assessing water quality changes in the lakes of the northeastern United States using sediment diatoms. Can J Fish Aquat Sci 56:131-152

Dudley B, Gunn IDM, Carvalho L, Proctor I, O'Hare MT, Murphy KJ, Milligan A (2012) Changes in aquatic macrophyte communities in Loch Leven-evidence of recovery from eutrophication? Hydrobiologia 681:49-57

Duigan C, Kovach W, Palmer M (2007) Vegetation communities of British lakes: a revised classification scheme for conservation. Aquat Conserv Mar Freshw Ecosyst 17:147-173

Fernández-Aláez M, Fernández-Aláez C, Rodríguez S (2002) Seasonal changes in biomass of charophytes in shallow lakes in the northwest of Spain. Aquat Bot 72:335-348

Fisher J, Barker T, James C, Clarke SJ (2009) Water quality in chronically nutrient-rich lakes: the example of the Shropshire-Cheshire meres. Freshw Rev 2:79-99

Goldsmith BJ, Luckes SJ, Bennion H, Carvalho L, Hughes M, Appleby PG, Sayer CD (2003) Feasibility studies on the restoration needs of four lake SSSIs. Final Report to English Nature Contract No. EIT 30-05-005. ECRC Research Report No. 87

Goldsmith B, Burgess A, Salgado J (2012) Lake SSSI Condition Assessment: compilation and interpretation of 2006-2010 data. SAE03-02-320/SAE03-02-380. Final Report to Natural England

Hall RI, Smol JP (2010) Diatoms as indicators of eutrophication. In: Stoermer EF, Smol JP (eds) The diatoms: applications for the environmental and earth sciences, 2nd edn. Cambridge University Press, Cambridge, pp 122-151

Heiri O, Lotter AF, Lemcke G (2001) Loss on ignition as a method for estimating organic and carbonate content in sediments: reproducibility and comparability of results. J Paleolimnol 25:101-110

Hutchinson SM (2005) The recent sedimentation history of Aqualate Mere (central England): assessing the potential for lake restoration. J Paleolimnol 33:205-228

IAFG, Interagency Freshwater Group (2015) Common standards monitoring guidance for freshwater lakes. JNCC, Peterborough, p 45
Jeppesen E, Madsen EA, Jensen JP (1996) Reconstructing the past density of planktivorous fish from sedimentary zooplankton fossils: a surface sediment calibration data set from shallow lakes. Freshw Biol 36:115-127

Jeppesen E, Søndergaard M, Søndergaard M, Christoffersen K (eds) (1998) The structuring role of submerged macrophytes in lakes. Ecological studies, series 131. SpringerVerlag, New York

Jeppesen E, Leavitt P, De Meester L, Jensen JP (2001) Functional ecology and palaeolimnology: using cladoceran remains to reconstruct anthropogenic impact. Trends Ecol Evol 16:191-198

Jeppesen E, Søndergaard M, Lauridsen TL, Davidson TA, Liu Z, Mazzeo N, Trochine C, Özkan K, Jensen HS, Trolle D, Starling F, Lazzaro X, Johansson LS, Bjerring R, Liboriussen L, Larsen SE, Landkildehus F, Egemose S, Meerhoff M (2012) Biomanipulation as a restoration tool to combat eutrophication: recent advances and future challenges. Adv Ecol Res 47:411-488

Juggins S (2003) $C^{2}$ User guide. Software for ecological and palaeoecological data analysis and visualisation. University of Newcastle, Newcastle upon Tyne, p 69

Kolada A, Willby N, Dudley B, Nõges P, Søndergaard M, Hellsten S, Mjelde M, Penning E, van Geest G, Bertrin V, Ecke F, Mäemets H, Karus K (2014) The applicability of macrophyte compositional metrics for assessing eutrophication in European lakes. Ecol Indic 45:407-415

Körner S (2002) Loss of submerged macrophytes in shallow lakes in North-Eastern Germany. Int Rev Hydrobiol 87:375-384

Kowalewski GA, Kornijów R, McGowan S, Woszczyk M, Suchora M, Bałaga K, Kaczorowska A, Gąsiorowski M, Szeroczyńska K, Wasiłowska A (2013) Persistence of protected, vulnerable macrophyte species in a small, shallow eutrophic lake (eastern Poland) over the past two centuries: implications for lake management and conservation. Aquat Bot 106:1-13

Levi EE, Çakıroğlu Aİ, Bucak T, Odgaard BV, Davidson TA, Jeppesen E, Beklioglu M (2014) Similarity between contemporary vegetation and plant remains in the surface sediment in Mediterranean lakes. Freshw Biol 59:724-736

Lyche-Solheim A, Feld CK, Birk S, Phillips G, Carvalho L, Morabito G, Mischke U, Willby N, Søndergaard M, Hellsten S, Kolada A, Mjelde M, Böhmer J, Miler O, Pusch MT, Argillier RT, Jeppesen E, Lauridsen TL, Poikane S (2013) Ecological status assessment of European lakes: a comparison of metrics for phytoplankton, macrophytes, benthic invertebrates and fish. Hydrobiologia 704:57-74

Madgwick G, Emson D, Sayer CD, Willby NJ, Rose N, Jackson MJ, Kelly A (2011) Centennial-scale changes to the aquatic vegetation structure of a shallow eutrophic lake and implications for restoration. Freshw Biol 56:2620-2636

Mainstone C, Hall R, Diack I (2016) A narrative for conserving freshwater and wetland habitats in England. Natural England Research Reports, Number 064, Natural England. ISBN 978-1-78354-303-8

McGowan S, Britton G, Haworth EY, Moss B (1999) Ancient blue-green blooms. Limnol Oceanogr 44:436-439

McGowan S, Leavitt PR, Hall RI, Anderson NJ, Jeppesen E, Odgaard BV (2005) Controls of algal abundance and 
community composition during ecosystem state change. Ecology 86:2200-2211

Moss B, McGowan S, Carvalho L (1994) Determination of phytoplankton crops by top-down and bottom-up mechanisms in a group of English Lakes, the West Midland Meres. Limnol Oceanogr 39:1020-1029

Odgaard B, Rasmussen P, Anderson NJ (1997) The macrofossil record of 20th century submerged vegetation dynamics in shallow Danish lakes. Würtzburger Geographische Manuskripte 41:153-154

Palmer MA, Bell SL, Butterfield I (1992) A botanical classification of standing waters in Britain: applications for conservation and monitoring. Aquat Conserv Mar Freshw Ecosyst 2:125-143

Penning WE, Dudley B, Mjelde M, Hellsten S, Hanganu J, Kolada A, van den Berg M, Poikane S, Phillips G, Willby N, Ecke F (2008) Using aquatic macrophyte community indices to define ecological status of European lakes. Aquat Ecol 42:253-264

Pentecost A (2009) The marl lakes of the British Isles. Freshw Rev 2:167-197

Phillips G (2003) Reporting typology for ecoregion 18, Great Britain. TAG/LTT 43, March 2003

Phillips G, Willby N, Moss B (2016) Submerged macrophyte decline in shallow lakes; what have we learnt in the last forty years? Aquat Bot 135:37-45

Pittam NJ, Foster IDL, Mighall TM (2009) An integrated lakecatchment approach for determining sediment source changes at Aqualate Mere, Central England. J Paleolimnol 42:215-232

Rasmussen P, Anderson NJ (2005) Natural and anthropogenic forcing of aquatic macrophyte development in a shallow Danish lake during the last 7000 years. J Biogeogr 32:1993-2005

Reynolds CS, Sinker CA (1976) The meres: Britain's eutrophic lakes. New Sci 71:10-12

Roelofs JGM (1983) Impact of acidification and eutrophication on macrophyte communities in soft waters in The Netherlands I. Field observations. Aquat Bot 17:139-155

Rørslett B, Brettum P (1989) The genus Isoetes in Scandinavia: an ecological review and perspectives. Aquat Bot 35:223-261

Rose NL (1994) A note on further refinements to a procedure for the extraction of carbonaceous fly-ash particles from sediments. J Paleolimnol 11:201-204

Rose NL (2008) Quality control in the analysis of lake sediments for spheroidal carbonaceous particles. Limnol Oceanogr Methods 6:172-179

Rose NL, Appleby PG (2005) Regional applications of lake sediment dating by spheroidal carbonaceous particle analysis I: United Kingdom. J Paleolimnol 34:349-361

Rose NL, Harlock S, Appleby PG, Battarbee RW (1995) The dating of recent lake sediments in the United Kingdom and Ireland using spheroidal carbonaceous particle concentration profiles. Holocene 5:328-335

Salgado J, Sayer C, Carvalho L, Davidson T, Gunn I (2010) Assessing aquatic macrophyte community change through the integration of palaeolimnological and historical data at Loch Leven, Scotland. J Paleolimnol 43:191-204

Sand-Jensen K (1997) Eutrophication and plant communities in Lake Fure during 100 years. In: Sand-Jensen K, Pedersen
$\mathrm{O}$ (eds) Freshwater biology: priorities and development in Danish research. GEC Gad, Copenhagen, pp 26-38

Sand-Jensen K, Riis T, Vestergaard O, Larsen SE (2000) Macrophyte decline in Danish lakes and streams over the past 100 years. J Ecol 88:1030-1040

Sayer CD, Burgess A, Kari K, Davidson TA, Peglar S, Yang H, Rose N (2010a) Long-term dynamics of submerged macrophytes and algae in a small and shallow, eutrophic lake: implications for the stability of the macrophytedominance. Freshw Biol 55:565-583

Sayer CD, Davidson TA, Jones IJ, Langdon PG (2010b) Combining contemporary ecology and palaeolimnology to understand shallow lake ecosystem change. Freshw Biol 55:487-499

Sayer CD, Davidson TA, Jones IJ (2010c) Seasonal dynamics of macrophytes and phytoplankton in shallow lakes: a eutrophication-driven pathway from plants to plankton? Freshw Biol 55:500-513

Sayer CD, Bennion H, Davidson TA, Burgess A, Clarke G, Hoare D, Frings P, Hatton-Ellis T (2012) The application of palaeolimnology to evidence-based lake management and conservation: examples from UK lakes. Aquat Conserv Mar Freshw $\backslash$ Ecosyst 22:165-180

Sayer CD, Davidson TA, Rawcliffe R, Langdon P, Leavitt P, Cockerton G, Rose N, Croft T (2016) Consequences of fish kills for long-term trophic structure in shallow lakes: implications for theory and restoration. Ecosystems 19:1289-1309

Smolders AJP, Lucassen ECHET, Roelofs JGM (2002) The isoetid environment: biogeochemistry and threats. Aquat Bot 73:325-350

Søndergaard M, Johansson LS, Lauridsen TL, Jørgense TB, Liboriussen L, Jeppesen E (2010) Submerged macrophytes as indicators of the ecological quality of lakes. Freshw Biol 55:893-908

Stokoe R (1983) Aquatic macrophytes in the tarns and lakes of Cumbria. FBA Occasional Publication No. 18. FBA

Strayer DL, Dudgeon D (2010) Freshwater biodiversity conservation: recent progress and future challenges. J N Am Benthol Soc 29:344-358

Union European (1992) Council Directive 92/43/EEC of 21 May 1992 on the conservation of natural habitats and of wild fauna and flora. Off J Eur Commun L206:7-50

Union European (2000) Directive 2000/60/EC of the European Parliament and the Council of 23 October 2000 establishing a framework for Community action in the field of water policy. Off J Eur Commun L327:1-72

USEPA (2009) National lakes assessment: a collaborative survey of the nation's lakes. EPA 841/R-09/001. Office of Water and Office of Research and Development, US Environmental Protection Agency, Washington, DC

van den Berg M (1999) Charophyte colonization in shallow lakes. Ph.D. Thesis, Vrije University, Amsterdam. RIZA Report 99.015

van den Berg MS, Coops H, Meijer ML, Scheffer M, Simons J (1998) Clear water associated with a dense Chara vegetation in the shallow and turbid Lake Veluwemeer, The Netherlands. In: Jeppesen E, Sondergaard M, Sondergaard $\mathrm{M}$, Christoffersen K (eds) The structuring role of submerged macrophytes in lakes. Springer-Verlag, New York, pp 339-352 
van Nes EH, Scheffer M, van den Berg M, Coops H (2002) Dominance of charophytes in eutrophic shallow lakeswhen should we expect it to be an alternative stable state? Aquat Bot 72:275-296

Vörösmarty CJ, McIntyre PB, Gessner MO, Dudgeon D, Prusevich A, Green P, Glidden S, Bunn SE, Sullivan CA, Reidy Liermann C, Davies PM (2010) Global threats to human water security and river biodiversity. Nature 467:555-561

Wiik E, Bennion H, Sayer CD, Willby NJ (2013) Chemical and biological responses of marl lakes to eutrophication. Freshw Rev 6:35-62

Wiik E, Bennion H, Sayer CD, Clarke S (2014) Assessing the status of marl lakes under the European Union Water Framework Directive-insights from contemporary and palaeolimnological studies of three English lakes. Fundam Appl Limnol 185:121-138
Wiik E, Bennion H, Sayer CD, Davidson TA, Clarke SJ, McGowan S, Prentice S, Simpson GL, Stone L (2015) The coming and going of a marl lake: multi-indicator palaeolimnology reveals abrupt ecological change and alternative views of reference conditions. Front Ecol Evol 3:82

Willby N, Pitt J-A, Phillips G (2009) The ecological classification of UK lakes using aquatic macrophytes. Science Report SC010080/SR2. Environment Agency, Bristol, UK. https://publications.environmentagency.gov.uk/skeleton/ publications/default.aspx

Zhao Y, Sayer C, Birks H, Hughes M, Peglar S (2006) Spatial representation of aquatic vegetation by macrofossils and pollen in a small and shallow lake. J Paleolimnol 35:335-350 